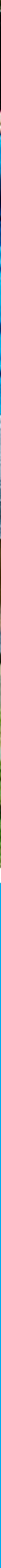




\section{WHAT'S INSIDE}

5 About the AYCC

62015 Highlights

8 From the National Director

9 From the Board Chair

10 Seed

12 Don't Risk the Reef

13 For the Love of

14 Switched on Schools

15 Youth Decide

16 National Volunteer Summit

17 Repower Port Augusta

18 People's Climate March

19 Climate Leaders

20 Our Movement Building

22 Past Leaders

24 Media \& Online

26 Our Supporters

27 Our Staff And Volunteers 


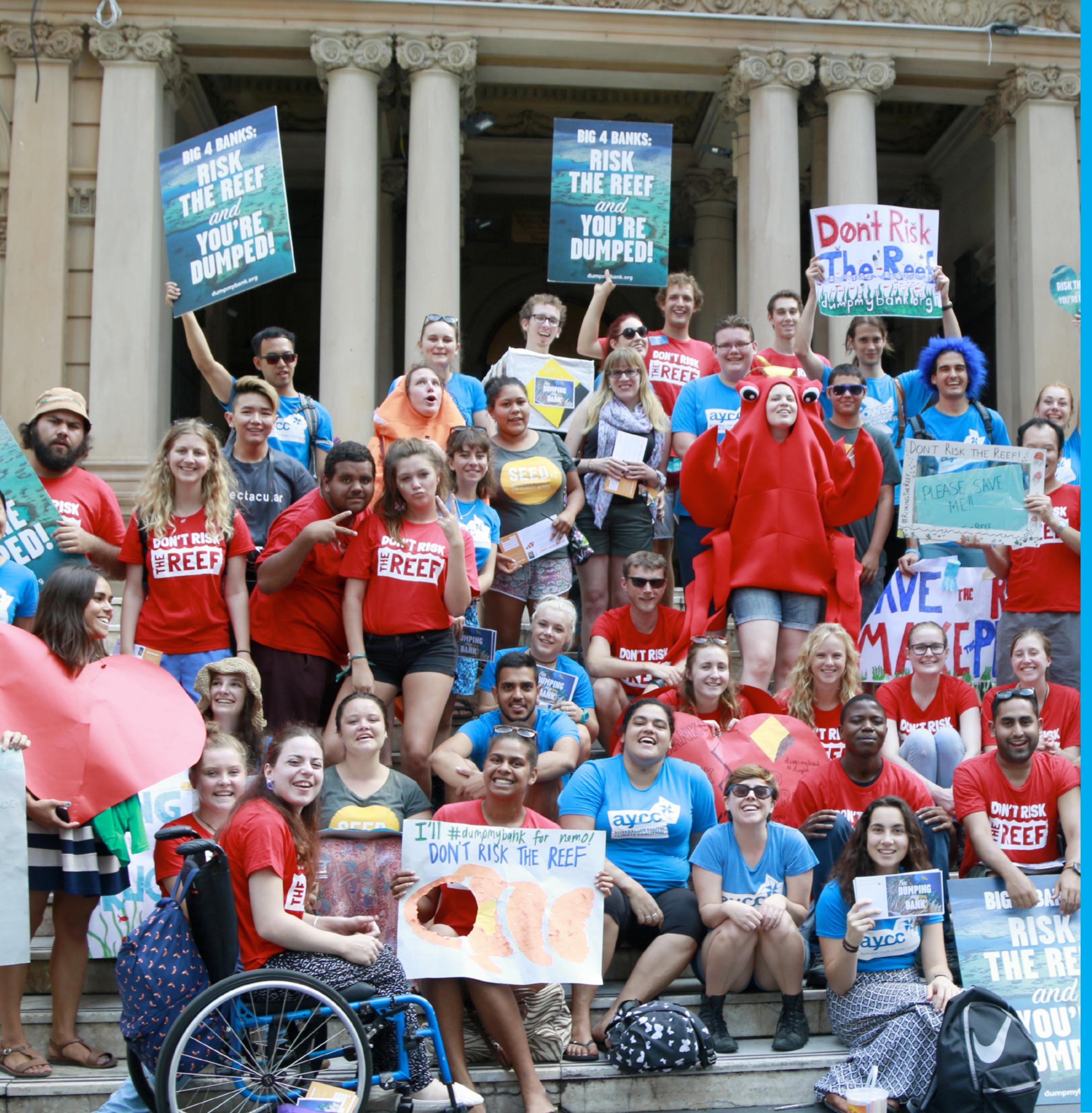

\section{ABOUT THE AYCC}

At the Australian Youth Climate Coalition and Seed Indigenous Youth Climate Network we are building a movement of young people to solve the climate crisis before it's too late. Our vision is for a just and sustainable world with a safe climate for our generation and future generations.

Since our Founding Summit in 2006, we have grown from a handful of students to one of Australia's largest youth-run organisations, with a network of more than 120,000 people and 1000 volunteers across the country.

We educate, inspire and mobilise young people to win campaigns for a safe climate, to keep fossil fuels in the ground and build a future powered by clean energy. We do this through:

- Seed Indigenous Youth Climate Network led by Aboriginal and Torres Strait Islander youth, Seed is a branch of the Islander youth to lead climate justice campaigns.

- National grassroots network where young volunteers are supported, through one-to-one mentoring and local groups, to be part of national campaigns that protect our climate.

Switched on Schools each year we educate thousands of high school students about how to make a difference on climate change, and empower them to start their own climate campaigns in their school or community.

- Training Program we are building the leaders of today with training programs that give young people the skills they change, campaigning, communication, organising and leading a team.

- National campaigns we work together as a movement to make a difference through campaigns that reduce climate pollution, move Australia beyond fossil fuels and supercharge the transition to $100 \%$ renewable energy. 
As 2015 draws to a close, it's hard not to be inspired by the achievements of young people across the country working for a safe climate future.

Thousands of young people pressured the big four banks to rule out involvement in massive new coal projects on the Great Barrier Reef coast. Through the Don't Risk the Reef campaign, young people held actions at more than a thousand bank branches and headquarters, spoke to tens of thousands of staff and customers, organised rallies, and came up with dozens of creative ways to reach the CEOs of the big banks in person and online.

And it worked! Thanks to young people, working with our friends in the movement, both NAB and Commonwealth Bank stepped away from the Galilee coal projects, and all four banks updated their climate policies.

On the other side of the country, young people in South Australia continued to support the Port Augusta community with their campaign to replace the ageing coal fired power stations with solar thermal. The community had sad news that the
stations will close in 2016 with no plan to transition the energy and jobs to renewables. However, the energy and jobs to renewables. However. grassroots pressure saw the SA Government
announcing a target of zero emissions by 2050 and Augusta in the next couple of years.

One of the things we're proudest about is the growth of Seed, which launched in October 2014, and is now a national network of Aboriginal and Torres Strait Islander young people leading campaigns for climate justice. In October Seed organised a road trip from Cairns to Brisbane meeting with Aboriginal and Torres Strait Islander communities facing the impacts of climate change and fossil fuel extraction. Young people collected these stories to help raise awareness of climate change impacts on Indigenous communities and country, and pressure the QLD Government to rule out support for coal expansion on the Reef.
Our work to educate and empower young people to take action on climate change expanded in 2015. We invested in a nine-month intensive skills in climate campaigning communication and organising We trained a further 400 young leaders through two day training camps, and 1000 high school students through our Switched on schools summits. We also launched a new hub for high school students to start their own climate campaigns in their school or community.

We finished off the year with 'Youth Decide' where 7000 students got to vote for the agreement they wanted world leaders to create in Paris. This coincided with marches we helped organise around the country, mobilising 170,000 people ahead of the Paris Climate Summit.

The historic agreement that world leaders agreed to in Paris makes it even more important for us to continue campaigning for a safe climate here in Australia. We were ranked third worst in the world for our climate policies, and continue to be one huge potential for renewable energy.

In 2016, AYCC and Seed are launching our Strategic Plan which will create a roadmap for our campaigns and movement building work over the next three years.

I wanted to say a massive thank you to everyone who has been a part of making 2015 possible - our volunteers, members, staff, board and all of our donors. We have made leaps and bounds in our sustainable fundraising this year with our for the Love of the Reef campaign where 4000 people donated $\$ 145,000$ to AYCC supporters who gave up chocolate, coffee or beer for two weeks to fund our Reef campaign. We also doubled our regular giving program and send a special thank you to all our Champions of Change who make it possible to plan ahead and be independent

Bring on 2016!

Kirsty Albion,

National Director
As we look back on 2015, it's inspiring to feel the powerful momentum that is being built by the global movement to combat climate change; and to know that the Australian Youth Climate Coalition is playing a vital role in adding strategic pressure and campaign successes to that movement.

This was a year of big wins for the AYCC, and one that demonstrated the power that we can wield as a movement. AYCC volunteers around the country continued to escalate the innovative Don't Ris the Reef campaign - pressuring Australian banks not to invest in the Abbot point coal port near the Great Barrier Reef. And after 18 months delivering creative, strategic actions from local branches to AGMS... ArCC members helped convince three of the four big domestic banks - Commonwealth Bank, NAB and Westpac - to update their climate policies and commit to take environmentel for finas for finance assistance. That's a commitment that effectively rules out domestic financing for the Abbot Point project, and brings us one critical step closer to protecting the reef.

On top of changing the policies of some of the biggest companies in the country, our National Leadership Team have also continued to lead remarkable work growing and strengthening our grassroots movement. They have mobilised hundreds of new young volunteers in schools, universities, regional towns and suburbs across the country - supporting volunteers to take their powerful message to decision-makers in ou parliaments, bank branches, and local communities.

This year I am particularly excited to celebrate the fantastic work of the Seed Indigenous Yout Climate Network, who have gone from strength to strength and now have Seed State Coordinators in most states across Australia. This is a critical milestone in the expansion of the network, and one that has been reached while the small but mighty eam driving Seed's work have also been delivering an impressive training and campaigning program.

2015 has been an incredible year thanks to the remarkable young people who make up the AYCC. On behalf of the volunteers who make up the Board, I would like to congratulate the tens of thousands of young people who have driven the AYCC's impact this year. I would also like to thank all of AYCC's generous funders and acknowledge the great work staff and volunteers are doing to grow sustainable forms of funding for AYCC. If you aren't already, I encourage you to join me in making a monthly donation to support the movement's critical work.

As we look back on 2015, I'd particularly like to congratulate the staff and volunteers that make up the National Leadership Team - you are leading a movement that's a force to be reckoned with, and their future aganst climate impacts. I impressed by your impact and leedership in the call for climate justice. I'd particularly like to thank Jem $\mathrm{Bamford}$ our Head of Campaigns, for her Jem I'm sure her efforts will continue to be felt into the future as the years of work she has put into training many of our leaders continues to pay off.

I'd also like to recognise and thank the Board members who have given so much of their time this year to support the organisation to achieve its goals.

To everybody who gives of their time, money and energy to support the AYCC - thank you for making this year of groundbreaking impact possible. We look forward to continuing to work alongside you in the fight for climate justice in 2016.

Renee Carr,
Board Chair 


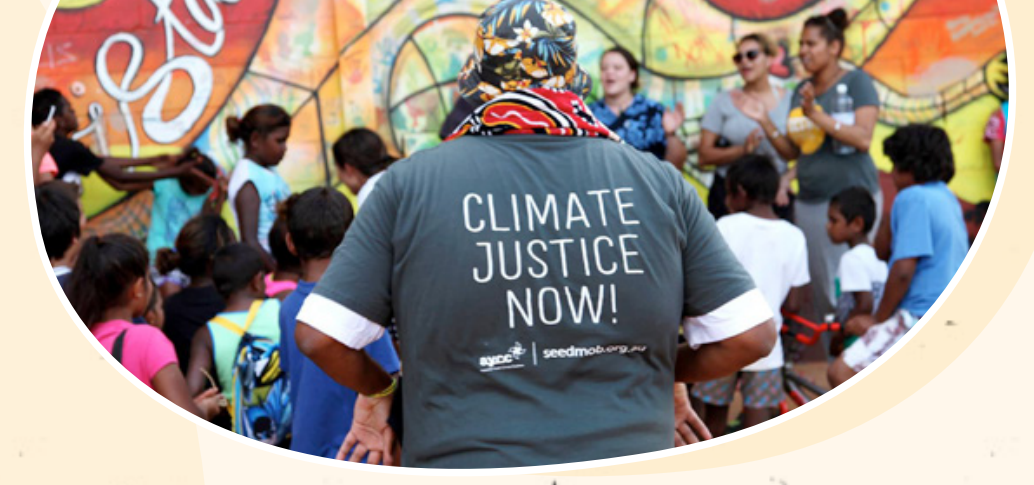

\section{S巨巨D |

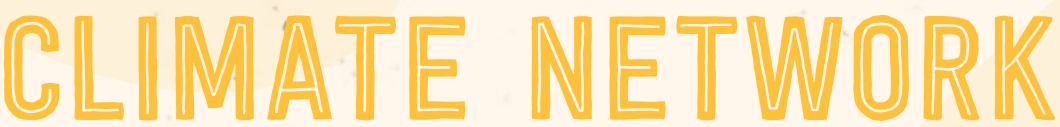

Throughout 2015 Seed has blossomed into a national network led by Aboriginal and Torres Strait Islander young people working to make climate justice real for our people. A series of key moments helped to build the agency, purpose and role for Seed in running campaigns that work to protect country from a changing climate and fossil fuel extraction, while also empowering our young people to be a part of creating positive change alongside the AYCC.

In August 2015 we introduced the Seed Leadership Team, which is made up of Seed staff and volunteer coordinators in each state and territory to support the growing base of volunteers. Managed by staff, this team organised the Queensland Seed Road Trip, helped organise the Peoples Climate Marches and assisted in facilitation throughout the intensive Climate Leaders training retreats.

Seed State Coordinators add crucial capacity to our constantly growing network. Our volunteers are spread throughout remote, rural, regional and urban communities right around Australia. Like any Indigenous organisation this creates challenges in how we communicate, connect and accurately represent our diverse young mob. Volunteer coordinators allow us to work in a way that respects our cultural obligations and ensures that our grassroots are supported and resourced. Seed's structure empowers all of our young mob .

During September to October 2015, 20 volunteers met with communities throughout Queensland who are witnessing the causes and impacts of climate change on their country to raise awareness resources to take action. This tied in with our work in supporting the Wangan and Jagalingou people to keep the Galilee basin coal in the ground.
The leadership of Aboriginal and Torres Strait slander people in the organisation and participation at the People's Climate Marches across the country in November is an example of the unique role Seed often plays in building bridges between modern environmental justice advocates and Indigenous struggles. At this time, we also saw Seed Victorian Co-Coordinator Paul Gorrie, address an International Indigenous roundtable on behalf of the Pacific region in Paris last December as part of the UNFCCC.

Our stories have spread far and wide as our voice continues to grow recognition on the issue of climate impacts on Aboriginal and Torres Strait Islander peoples. Through creating our own online platforms alongside national media stories from Indigenous and mainstream outlets, we have por internationally.

Seed has been awarded the 2015 Volunteering Victoria Award for Inclusion and named as finalists for the Premiers Sustainability Awards. Our National Director has received the 2015 Australian Geographic Society's Young Conservationist award and the 2015 Bob Brown Young Environmentalist of the Year award, which is recognition on behalf of the entire Seed team who have been a part of building our the ACT Vanessa Farrelly, also received ACT Young Environmentalist of the Year in 2015

\section{ROAD TRIPPED 180OKM THROUGH QUEENSLAND}

\section{AMAZING SEED STATE COORDINATORS \\ 8 COMMUNITY EVENTS}

\section{REACHED 25,000 PEOPLE} ONLINE EACH MONTH

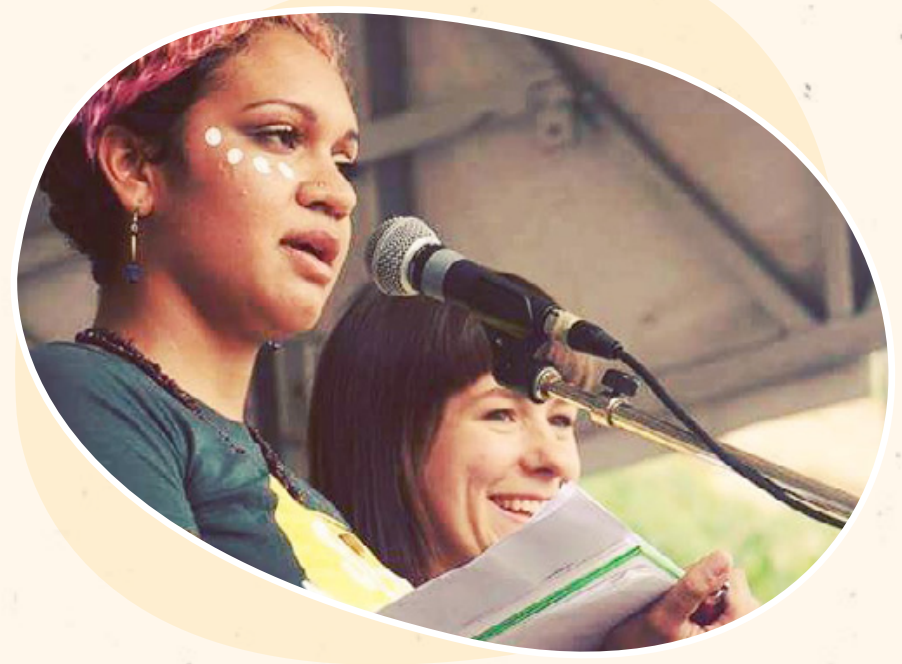

seedmob.org.au



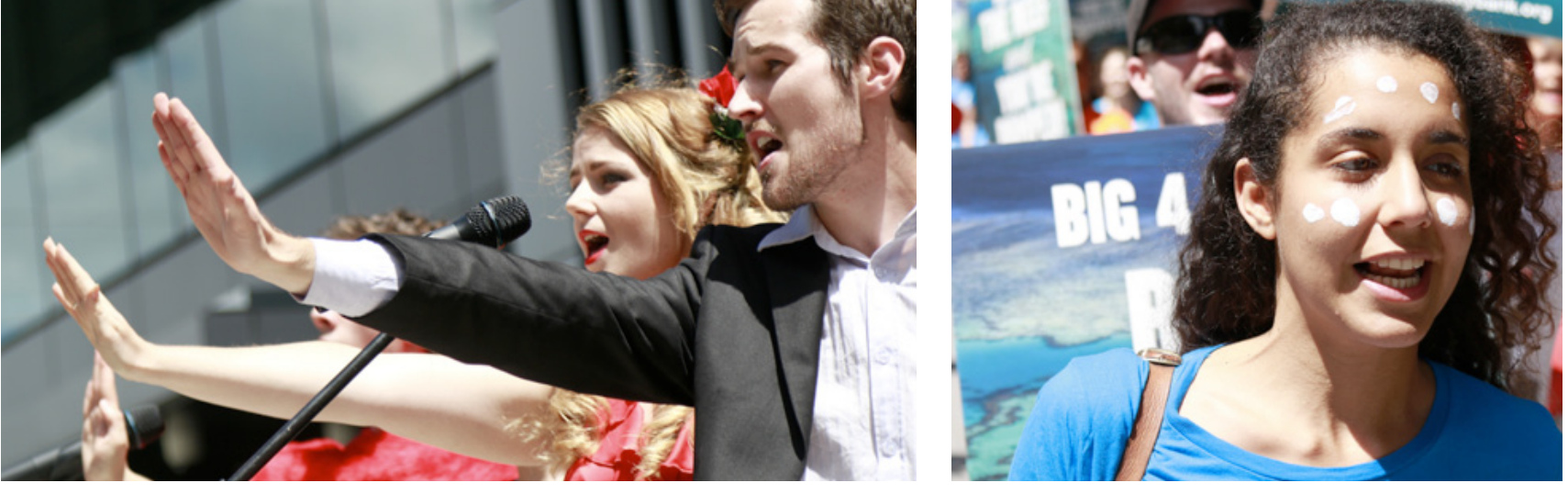

\section{DON'T RISK THE REEF}

2015 has seen some huge successes for AYCC's Don't Risk the Reef campaign. With our friends in the climate movement, we took on Australia's biggest banks, and won!

Groups have been campaigning since to 2013 expansion in central Queensland on the country of the Wangan and Jagalingou people. For Adani to build huge mega mines in the Galilee Basin in Queensland, and the construction of coal ports on the Great Barrier Reef coast they need finance from Australian banks. We knew we were perfectly placed with our decentralised grassroots network volunteers to target Australia's big 4 banks to help stop this from happening

Our Don't Risk the Reef campaign started in July 2014, but kicked off for this year at our National Summit in February with 240 volunteer leaders. After learning the skills needed to roll out the campaign, we held a Valentine's Day flashmob out the front of Commonwealth Bank $\mathrm{HQ}$ calling on them to withdraw from the project.

Over 18 months, AYCC and Seed volunteers have held 1000 actions at bank branches and HQs; raised awareness with thousands of staf by handing out flyers (and sometimes even home baked cupcakes!)
got 7000 customers to pledge to move their money; flooded the banks' social media pages; held money; flooded the banks social media pages,
creative actions at bank AGMs, public events and
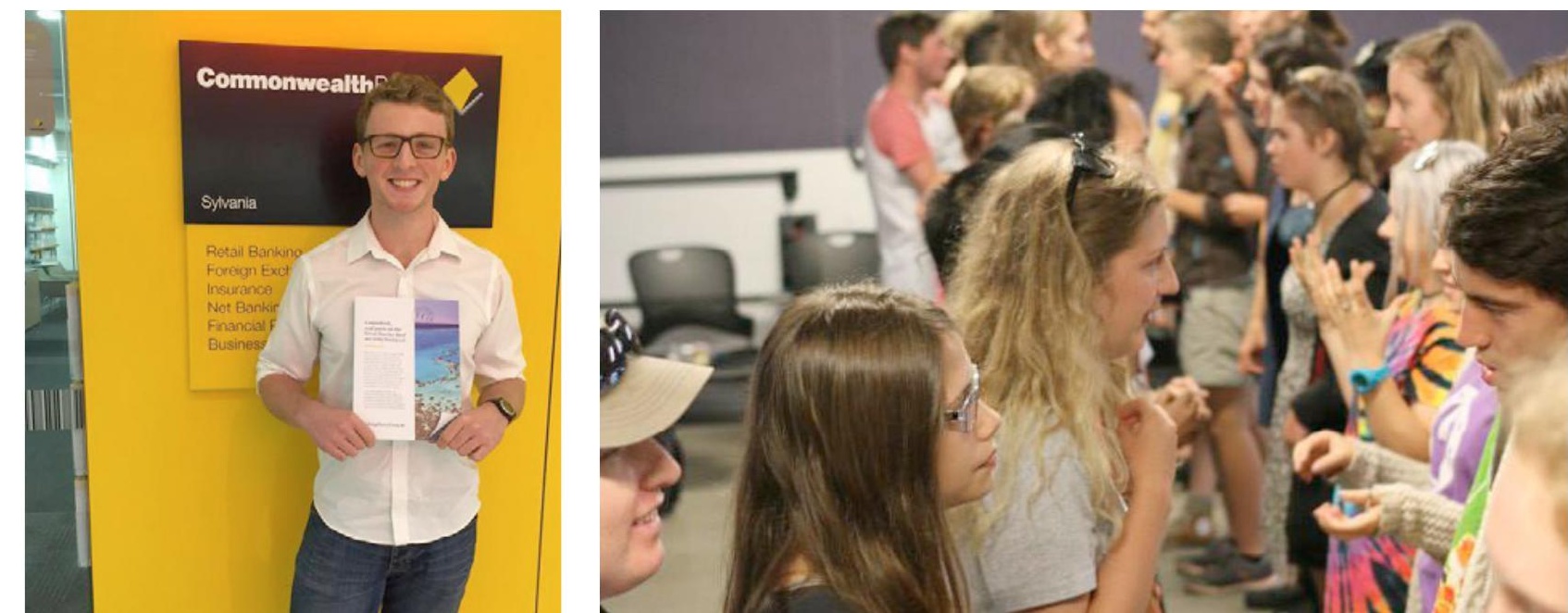

speeches; ran a guerilla ad campaign with tens of thousands of (recycled) posters and ATM screens: and held massive rallies at bank branches.

In August, we saw our first win! Commonwealth Bank announced that they were walking away from their advisory role on Adani's projects. Then, just a few weeks later NAB followed suit and publicly ruled out finance.

We then launched a Westpac staff survey. Our volunteers spoke with 2000 staff members across the country in a single week. The results came back that $90 \%$ of staff surveyed did not support their involvement in Adani's projects. We kept up the pressure with weekly $\mathrm{HQ}$ and branch actions in the lead up to their AGM. At the AGM we saw Westpac release new language which would make it very It was a huge year and we send a massive thanks to the countless hours invested by AYCC and Seed volunteers, working closely with many organisation and communities across the country. There is still a lot of work to be done in 2016 to protect our climate from these projects going ahead.
OUR IMPACT

- 2000 BANK STAFF MEMBERS CONVERSATIONS IN ONE WEEK

- 1000 ACTIONS AT

BANK BRANCHES

-500 ATM SCREENS COVERED WITH OUR MESSAGE

- $90 \%$ OF WESTPAC STAFF DON'T WANT THEIR EMPLOYER TO INVEST IN ADANI

2 BANKS REFUSED TO FINANCE ADANI'S COAL PROJECTS

- ALL 4 BIG BANKS UPDATED THEIR CLIMATE POLICES
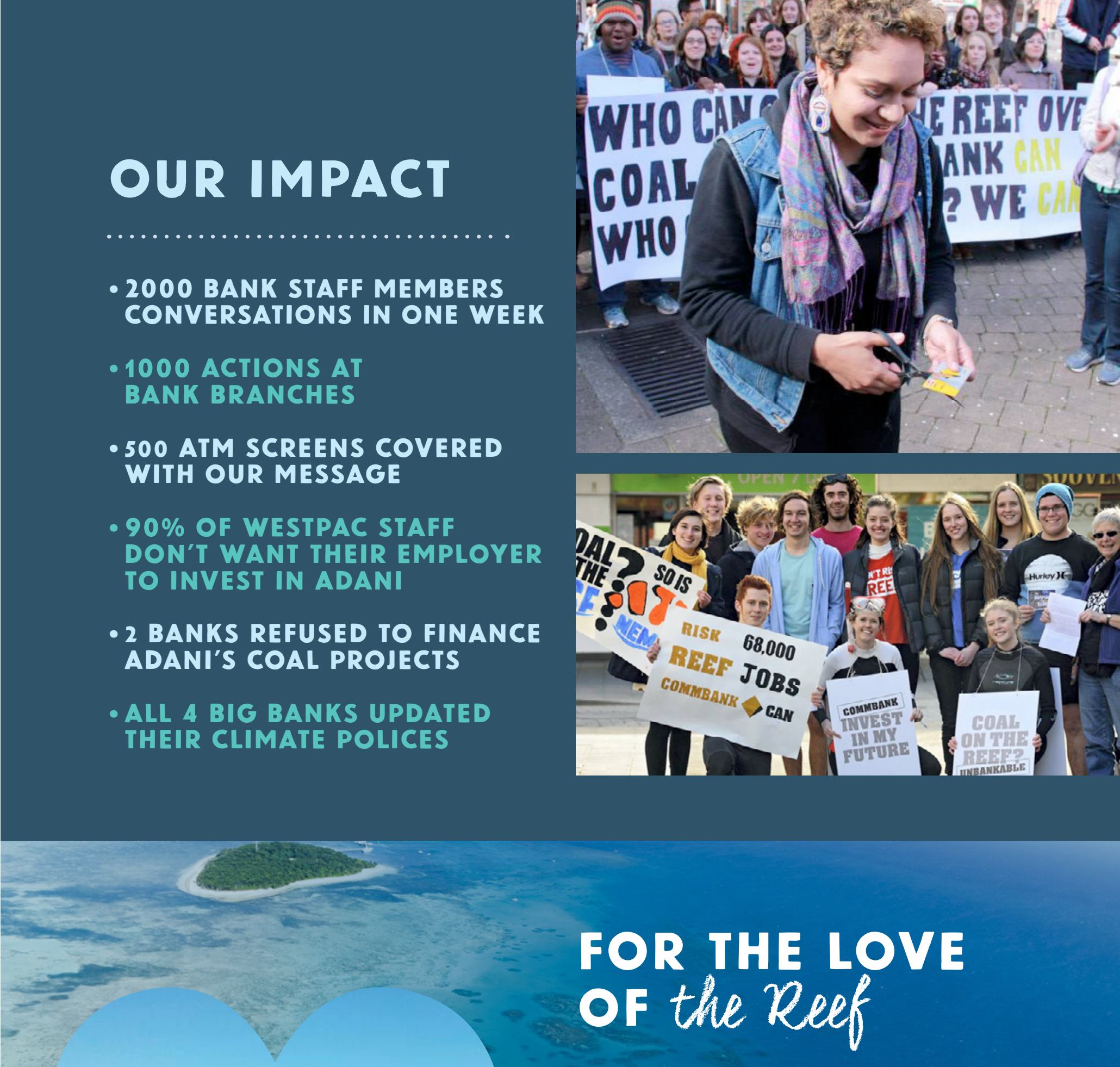

AYCC's Don't Risk the Reef campaign was one of the most successful in our history. But to fund through a campags and through awareness, we needed a fun and new way Great Barrier Reef.

That's why from the 18th to the 31st of May, 1,324 participants from across Australia joined together to raise funds and awareness to protect the Reef and our climate. For the Love Of the Reef was the first national peer-to-peer fundraising campaign we have ever run, and it was a huge success! For the love of the Reef, participants went without something else that they love - coffee, chocolate or beer - for two weeks as they raised funds and awareness in their communities. With over 4.000 donations they RAISED $\$ 145,000$ FOR AYCC CAMPAIGNS AND PROGRAMS. 


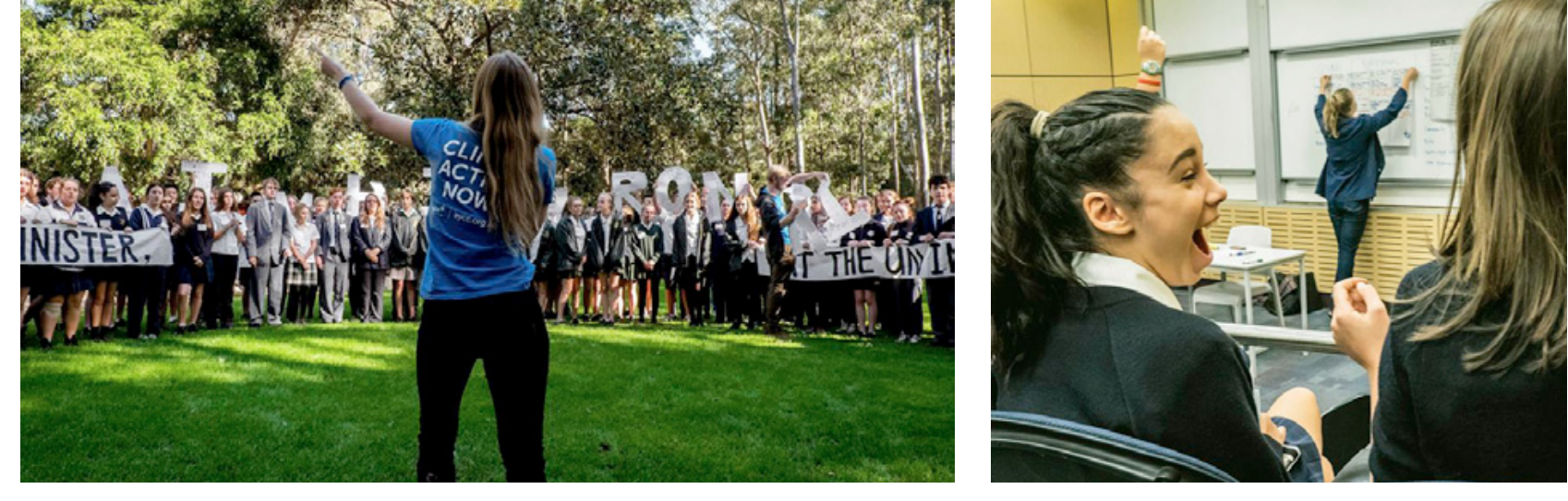

\section{SWITCHED ON SCHOOLS}

The Switched on Schools program has gone from strength to strength, and in 2015 reached more students than ever before empowering them to create change in their communities and imagine a better future for our generation.

The Switched on Schools program is one of Australia's foremost sustainability education programs focusing on high school students. We believe that young people have the skills, passion and creativity to create change on a local level, and by being part of a national youth movement can become change makers for life.

We work in partnership with local government, state government and a range of NGOs and community groups, to deliver transformational summits for 100 for houng people by students learn a bout climate change impats and solutions, and gain the skills and inspiration they need to lead their own climate campaigns in they school or community. THROUGH SUMMITS

- HELD 8 TWO=DAY SUMMITS AND 2 REGIONAL WORKSHOPS
- EMPOWERED 1000 STUDENTS
This year we launched our Switched on Schools online hub where students can acces educational resources, start their own climate campaigns and be part of national campaigns. This year 17,000 students were engaged through our online hub. We also developed Student Climate Action Networks (SCAN) in capital cities across the country, so students can be part of a peer-to-peer support network.

We'd like to thank our partners for your invaluable support in making our program stronger, helping empower a new generation of climate leaders, and for standing with us in our vision for a better world.
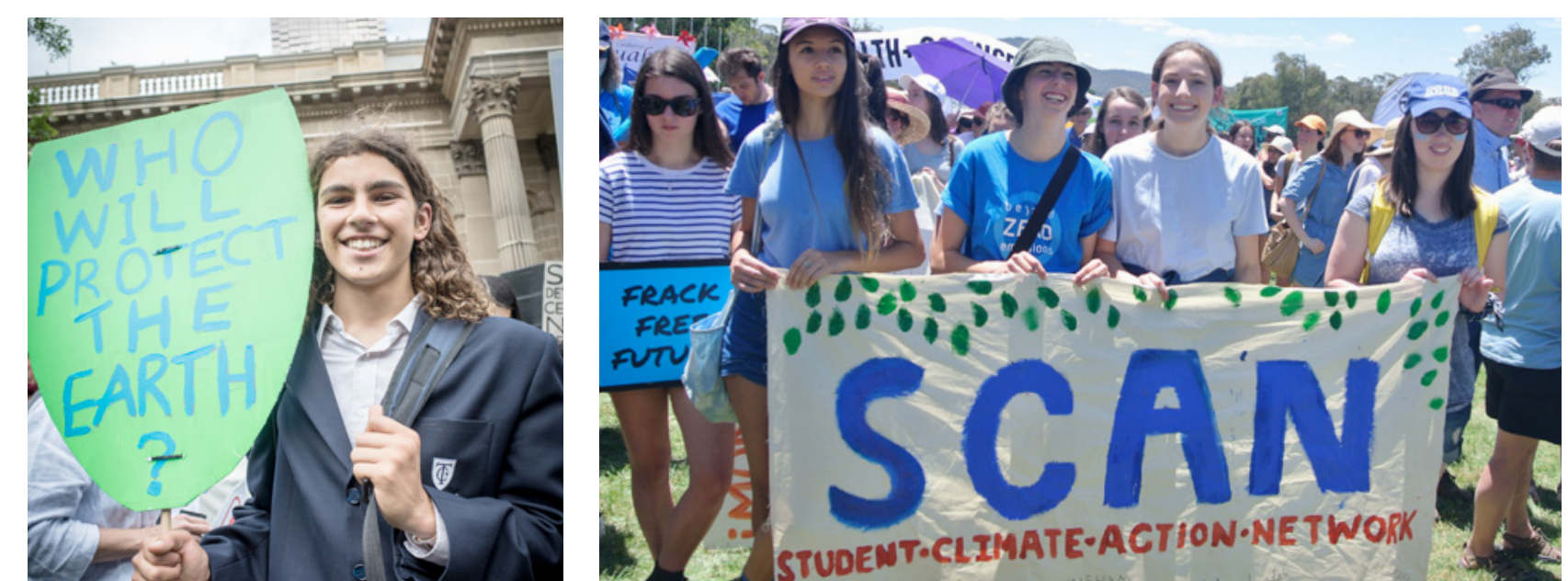

\section{POUTHDECIDE}

in Term 4, in the weeks before world leaders met Paris, thousands of high school students across the country had their say on the future they want to grow up in. We held Youth Decide, a national vote for igh school students, to let world leaders know what policies they wanted them to adopt in Paris.

On the online platform students learnt about the mpacts of global warming on three young people, and Australia's role in reaching solutions on a global scale. The campaign also encouraged students to eve ened

it was our first ever high school campaion and 7000 tudents voted from 350 schools. The votes were then delivered by AYCC and Seed volunteers to world eaders at the Paris Climate Summit.
NATIONAL YOUTH VOTE ON CLIMATE

. 7000 HIGH SCHOOL STUDENTS VOTED

-100 STUDENT=LED VOTING EVENTS

- 350 SCHOOLS PARTICIPATED

- $90 \%$ OF STUDENTS VOTED TO KEEP WARMING TO 1.5 DEGREES

- VOTES DELIVERED TO WORLD LEADERS IN PARIS
- 40 STUDENT=LED CAMPAIGNS

- 350 SCHOOLS PARTICIPATED
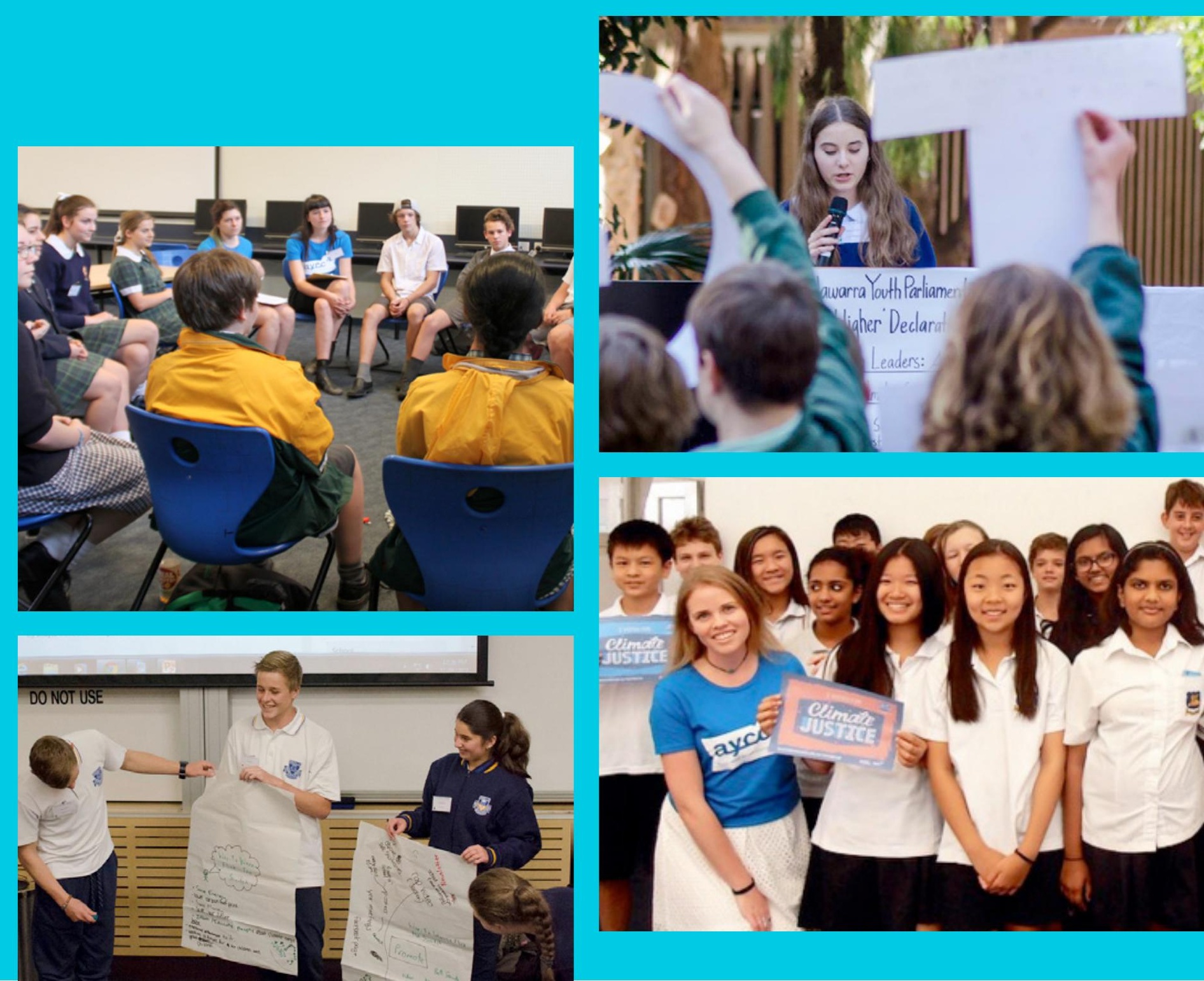
NATIONAL VOLUNTEER SUMMIT

Our February National Summit kicked off a huge year for the AYCC and Seed. This training event brought together over 240 people from every state and territory, including 30 Aboriginal and
Torres Strait Islander young people from the Seed Torres Strait Islander young people
Indigenous Youth Climate Network.

Over three days of workshops, panels, discussions and planning this event created a space where new and experienced volunteers deepened the level of engagement in taking action and creating positive change.

At the National Summit we held an action on Global Divestment Day alongside our friends from Greenpeace and 350.org. On Valentines Day volunteers serenaded staff with a version of "Stop in the name of love!" in front of Commonwealth Bank $H Q$, calling on them to cancel their role in supporting the Galilee coal projects. They then flooded the streets of Sydney speaking to thousands of people about moving their money to protect the Reef and our climate.
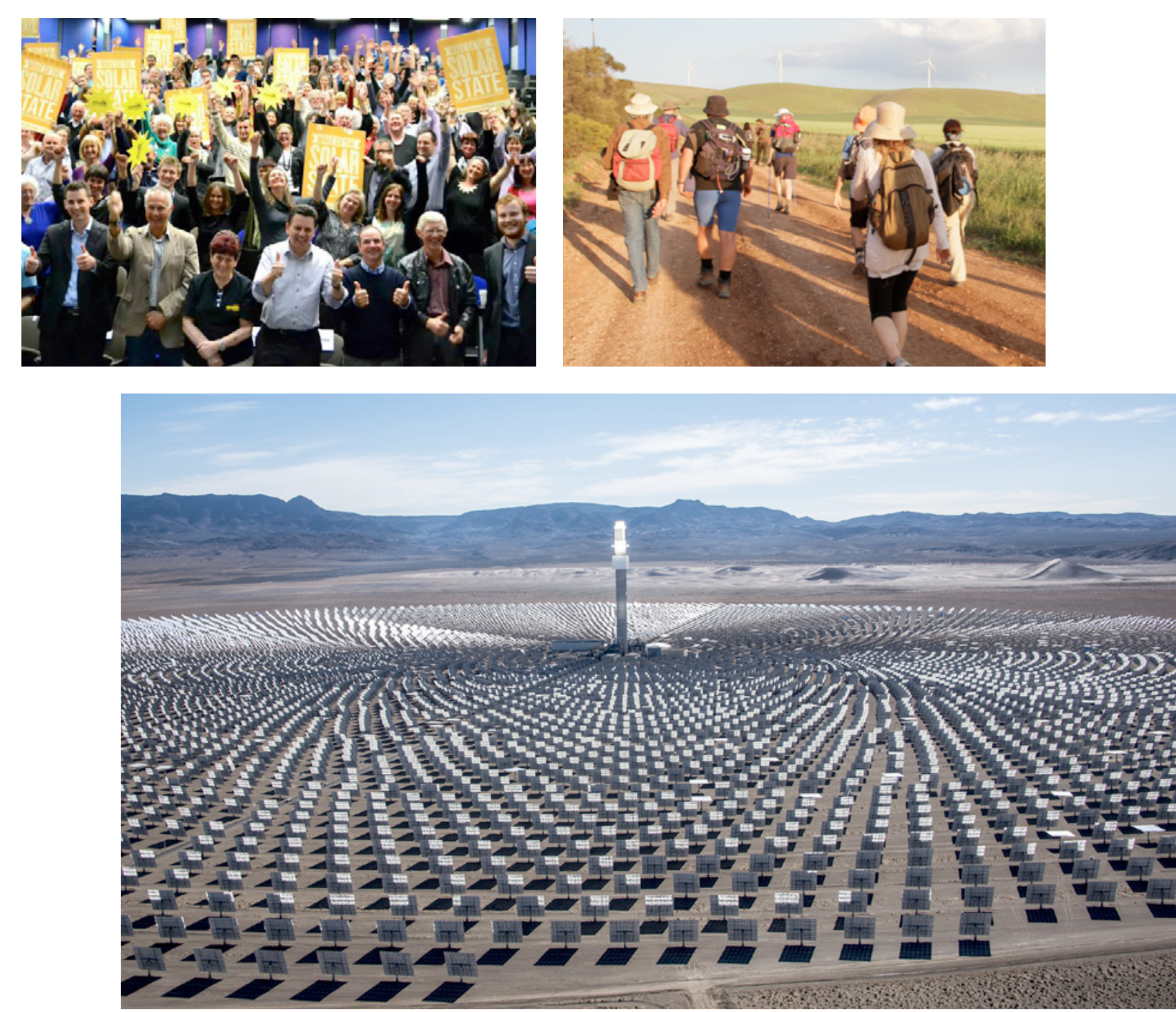

\section{REPOWER PORT AUGUSTA}

Repower Port Augusta has grown of even greater importance in 2015 with the closure of the Port Augusta coal station brought forward 15 years to March 2016. Our thoughts are with workers
who missed the opportunity for a just transition who missed the
in Port Augusta.

Repower Port Augusta has come a long way in 2015 with it being announced that US solar therm company SolarReserve have made a bid to the ACT government's next generation solar auction to supply power to the ACT from a solar thermal plant in Port Augusta. The outcome of this bid is still being waited on but having a company putting up their hand to build solar thermal has been a majo

The AYCC has continued to work alongside the Port Augusta community to build pressure for action from State and Federal politicians and this has resulted in the State Government announcing they from ny from new clean energy projects and have opened invest for bidding. This is a policy that could drive outcome should be announced in 2016 . Thank you to everyone in the Port Augusta community, South Australia and across the country who've kept up the fight for solar thermal in campaign development in 2015 


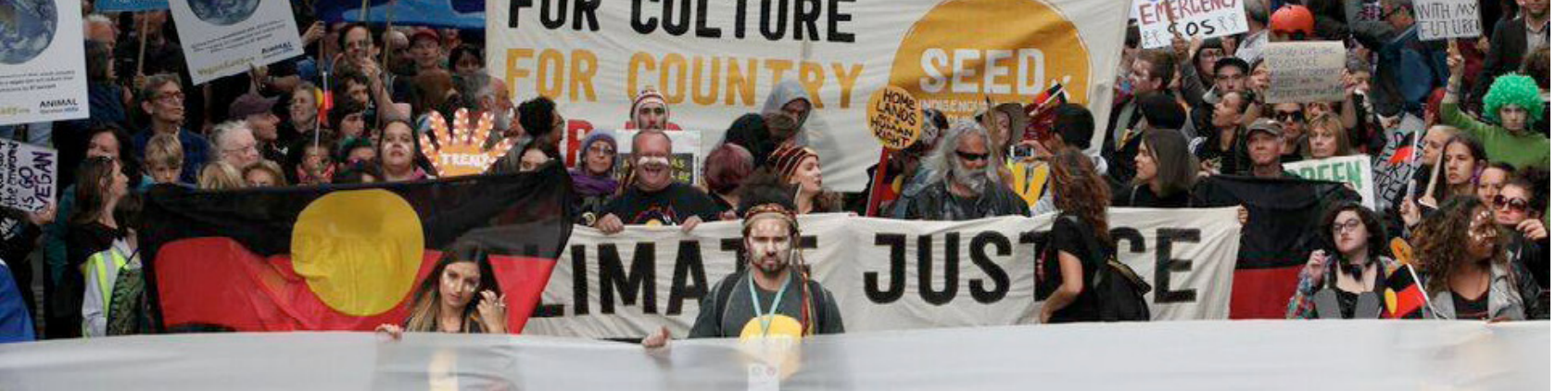

RenD FE FIIEATE MADCH

\section{PEOPLE'S CLIMATE MARCH}

Days before the start of the UN climate summit in Paris, Australians took to the streets in record numbers to show politicians what reat leadership on marched in over 200 events across Australia!

But beyond the sheer number of people who turned out, what was most exciting was the diversity of groups who stood together for climate justice. From Aboriginal and Torres Strait Islander peoples marching up front for culture and country, to people of faith, Pacific Islanders, unions marching for a just transition, and young people marching for our future and climate justice. (On our own we are strong, but together we are so much more powerful)
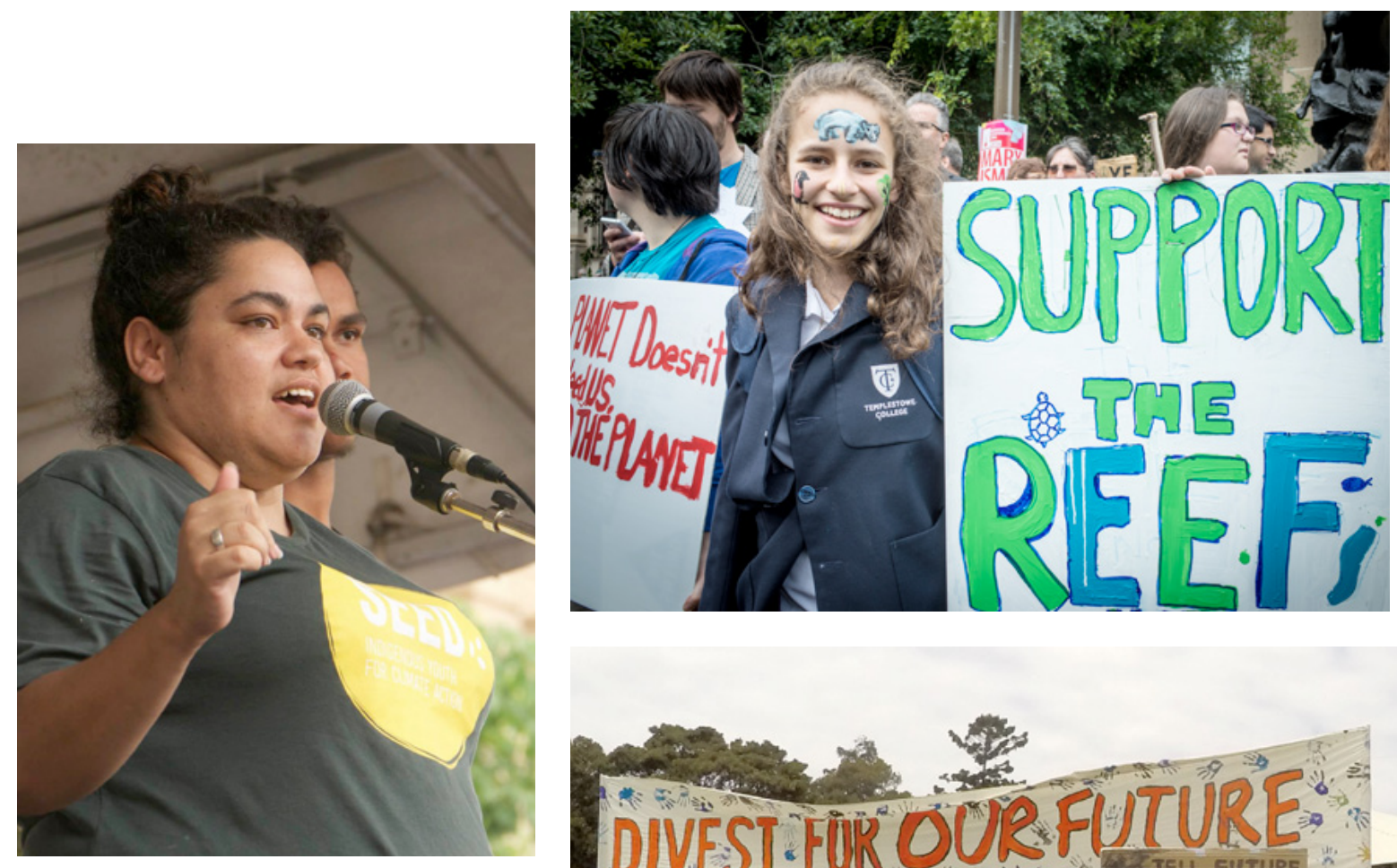

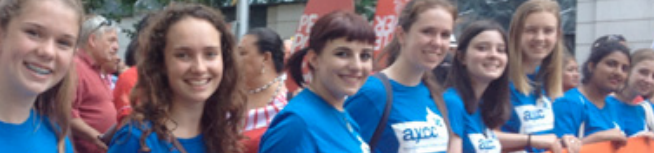
.

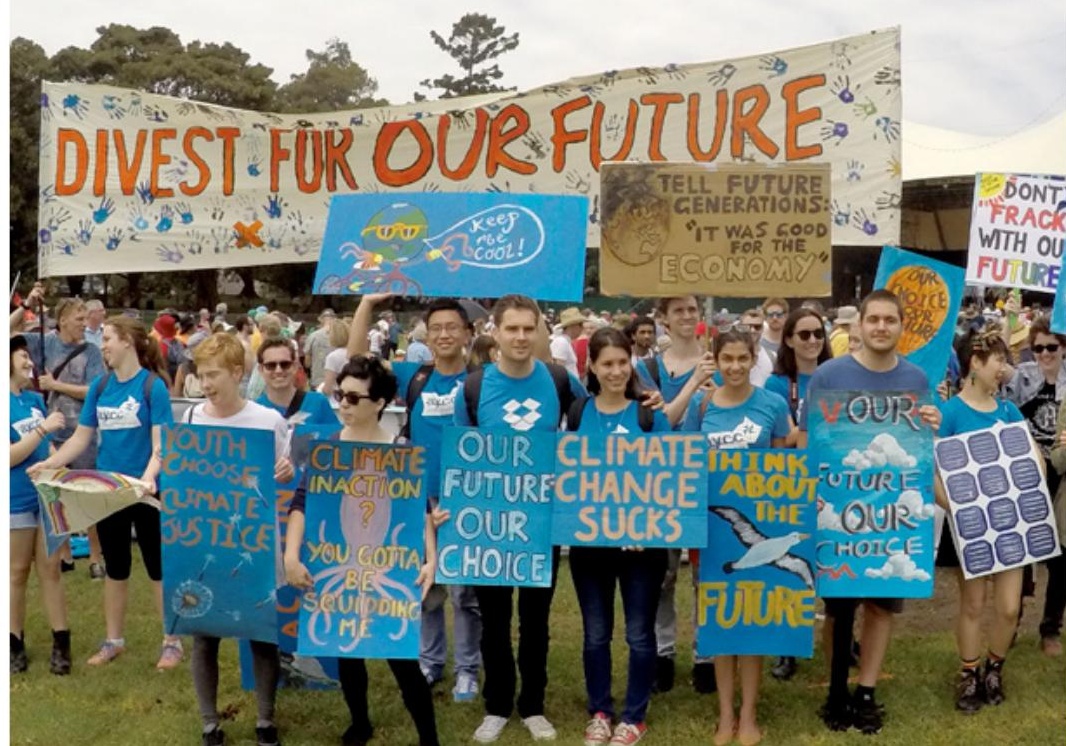

In Adelaide and Brisbane AYCC was the lead organisation for the march, and AYCC or Seed marches together. Hundreds of volunteers put up help get the incredible turn out we witnessed. Thank you to everyone who was part of the historic collaboration that made these marches possible over 300 partner organisations worked together paving the way for an incredibly strong climate movement in 2016. volunteers in every capital city were on the state organising committees that pulled these epic
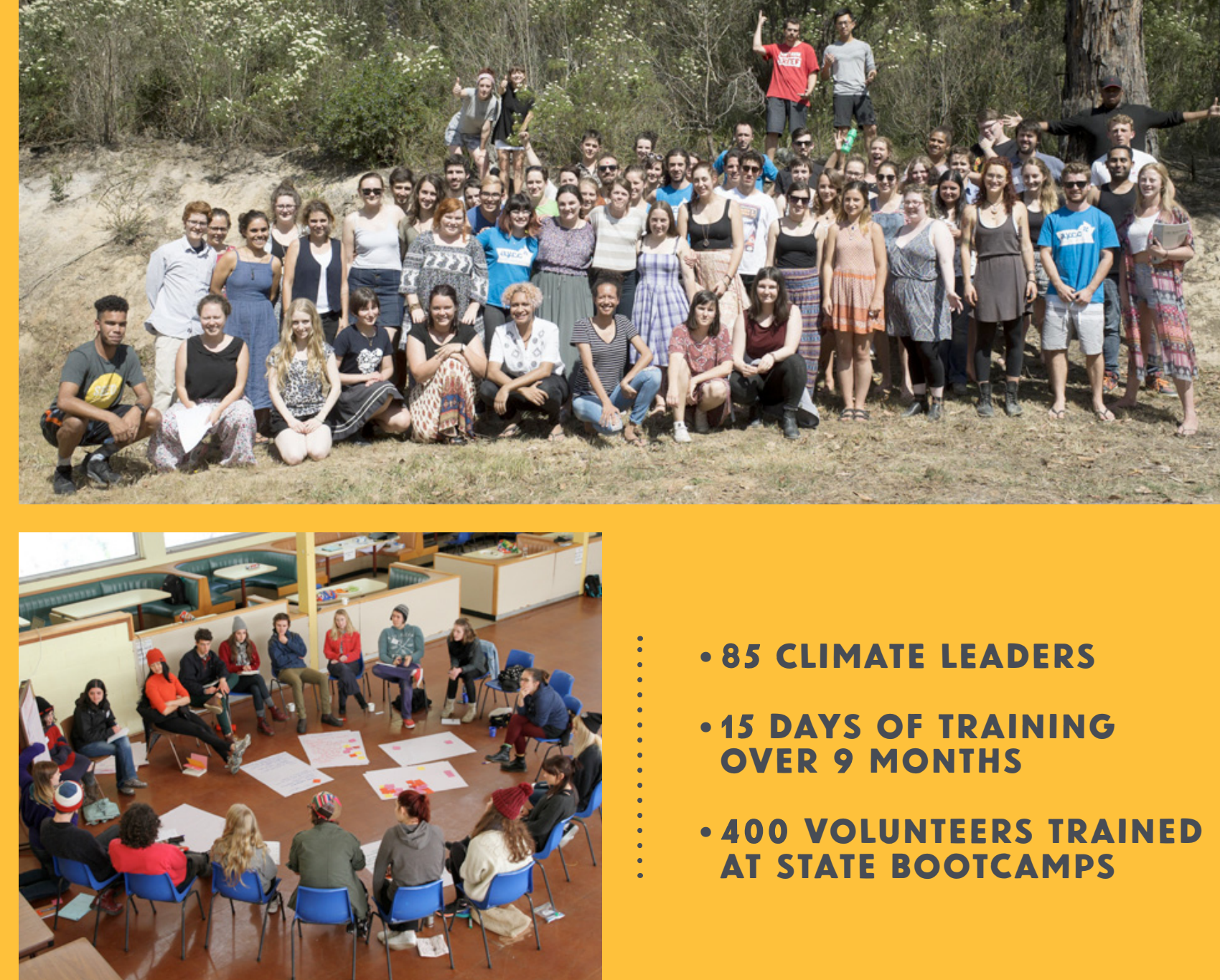

TRAINING UP THE NEXT GEN OF CLIMATE LEADERS

Our Training Program is a cornerstone of our movement-building and campaigning work. Each year we develop hundreds of young people to have a sense of their own power, and the skills, knowledge and networks to lead building up the size and capacity of core and committed volunters by:

Giving them foundational skills and knowledge in climate justice organising, campaigning and communication

- Building relationships between volunteers at a state and national leve

- Aligning our grassroots movement behind strategic campaigns, so together we can have the biggest impact:

- Investing in individuals to have the confidence and support to become lifelong climate leaders.
- 85 CLIMATE LEADERS

-15 DAYS OF TRAINING OVER 9 MONTHS

- 400 VOLUNTEERS TRAINED AT STATE BOOTCAMPS

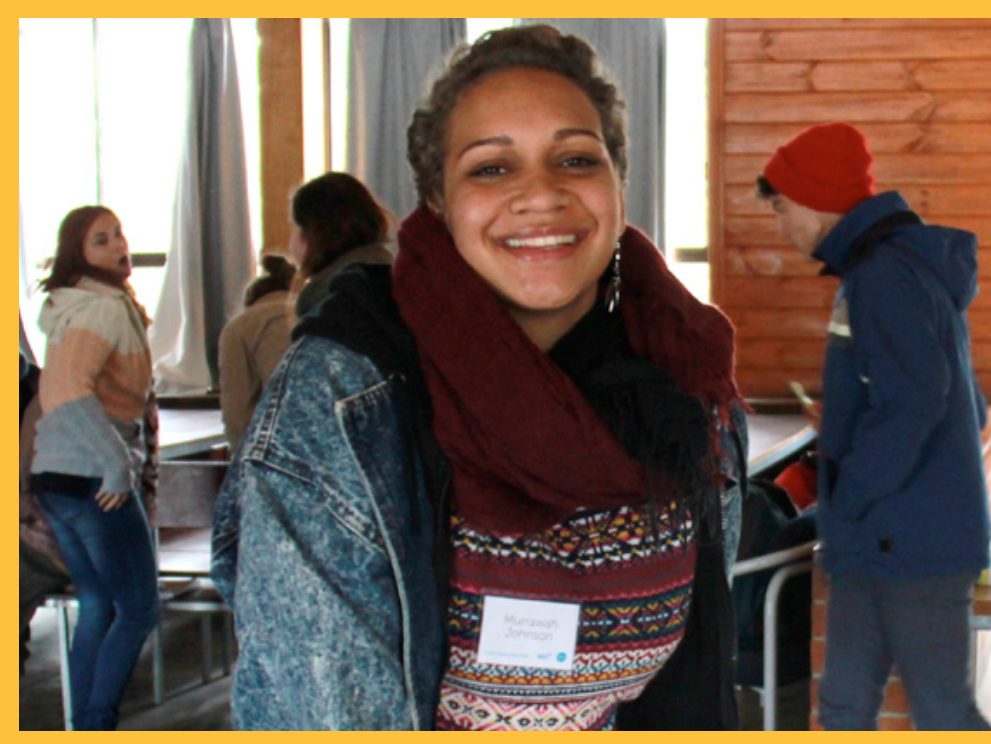

In 2015 held our first ever Climate Leaders program a nine-month intensive training program for 85 young leaders from the AYCC and Seed. Over 15 days of training at three national retreats, these young people gained skills in climate justice organising, campaigning and communication. These skills were strengthened through taking one-to-one campaigns and programs in their community.

Through state and regional boot camps we trained a further 350 young people in foundational skills social action skills, including communicating climate change building local groups and organising young people. mentoring and practical experience leading our 


\section{OUR MOVEMENT BUILDING}

In 2015 our grassroots groups across the country thrived. Our power comes through our volunteers who continue to go above and beyond in the fight against climate change. Here are a few of their stories in 2015.

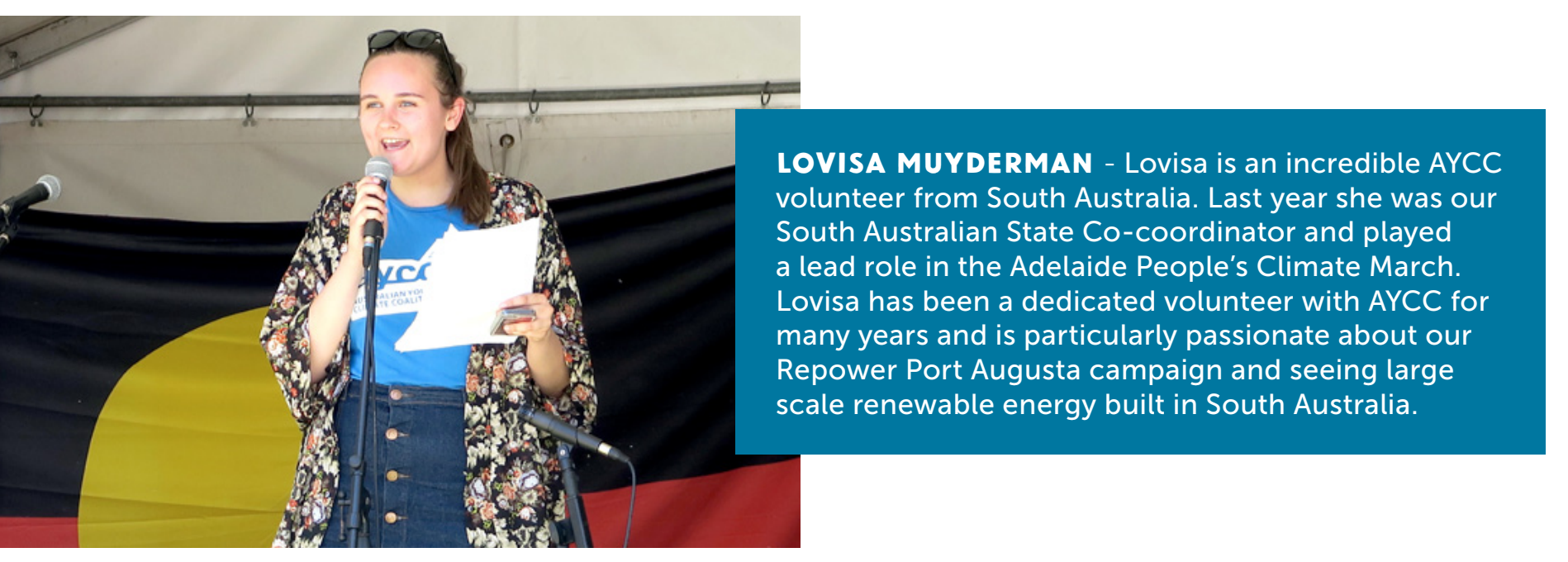

"AYCC'S SUPPORT FOR COMMUNITIES ON THE FRONTLINES OF BOTH FOSSIL FUEL EXTRACTION AND CLIMATE IMPACTS MAKES ME PROUD TO BE A PART OF THE ORGANISATION." Lovisa Muyderman

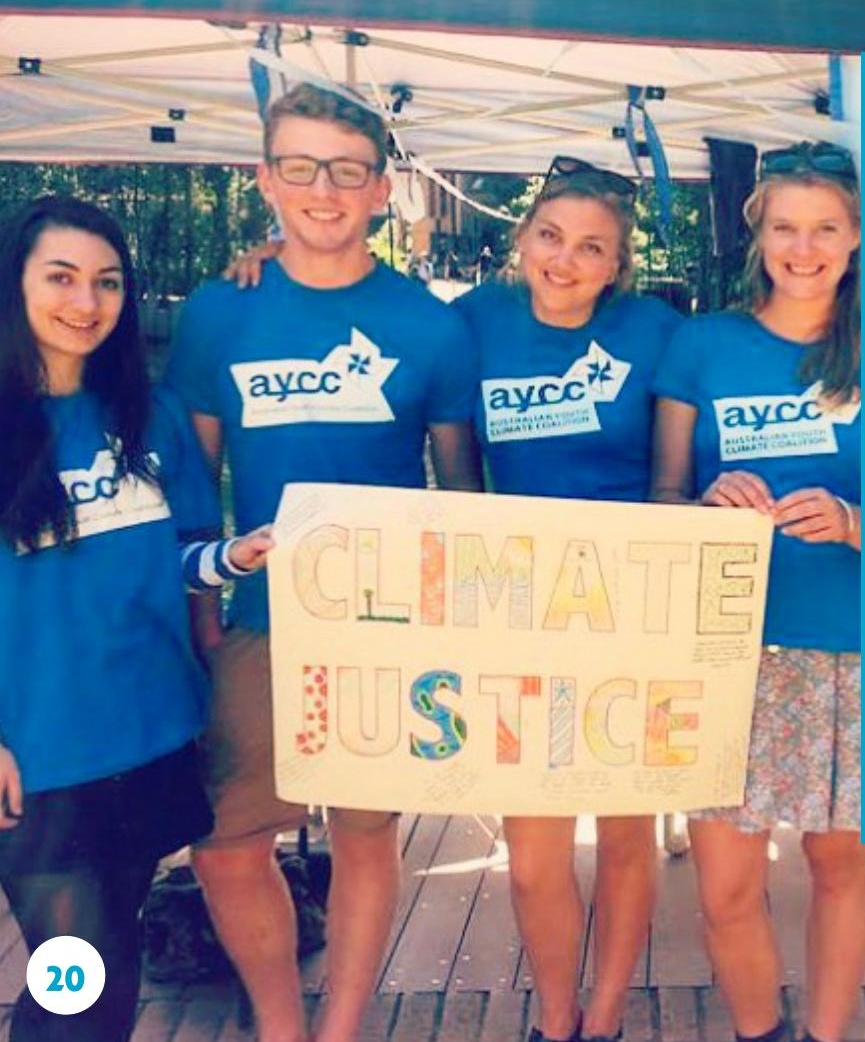

AYCC WOLLONGONG - we want to give a shout out to one local group in particular who went absolutely above and beyond in 2015. A special shout out to the AYCC Wollongong group. In 2015 they continued to grow the size and the volunteers who have achieved some amazing things. In 2015 the group ran the largest schools summit ever run in NSW with 150 high school students attending and taking part in the Illawarra Youth Parliament which made state news. The group were also able to lead the Global Climate Change Week initiative at the University of Wollongong (UOW) running climate justice stalls, coordinating a flashmob and recruiting over 50 Illawarra young people to attend the People's Climate March in Sydney. The group have done so well in 2015 that they are planning to expand regionally in 2016 , starting groups on UOW campuses down the south coast of NSW. Go team Wollongong!

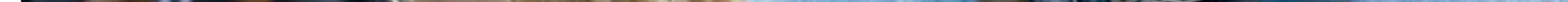




\section{WHAT OUR PAST LEADERS HAVE ACHIEVED}

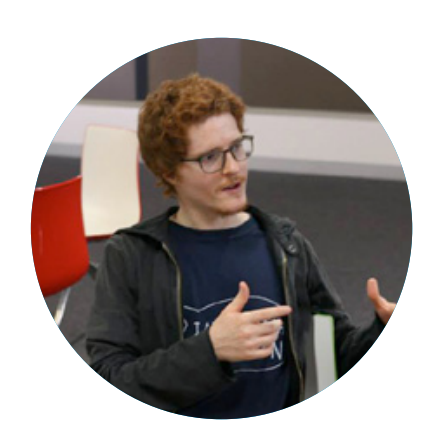

\section{MAX SMITH}

In my job as a community organiser with the Australian Conservation Foundation get to build people's connections, skills and capacity for collective action.

Last year ACF led the People's Climate March in Melbourne, where 60,000 people turned out to demand our leaders take strong action to build a better, safer and fairer future for all. I was responsible for mobilising ACF's supporters to reach out beyond the climate movement. The best part for me was how Australians, unions, farmers, firefighters, teachers and students, health workers, as well as business and faith leaders, all working together for the same goal.

When I came to AYCC I was a student who felt climate change was this really important thing, but none of our leaders were doing anything about it. I knew I wanted to get involved in trying to change this, but wasn't sure how. AYCC taught me how $I$ could be a leader for positive change - it gave me a sense of place and of purpose, a community of amazing like-minded people and about. I learnt a lot from my time here, and made some lifelong friends.

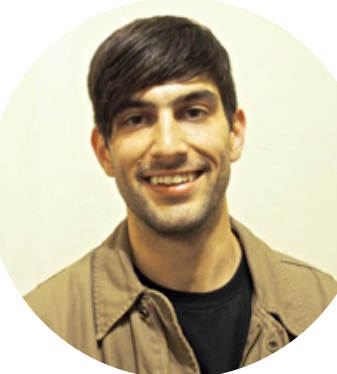

\section{CAMERON WHEATLEY}

This year I became the Communications Officer at Environment Victoria. My job is really varied - from design to social media, web content to helping write for the enpigns we run. It's a inays important to question how we motivate

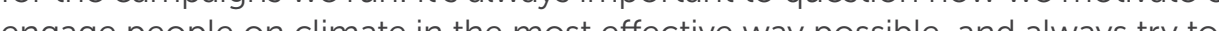
engage people appeal to people's se

AYCC helped me get to where I am in so many different ways. I gained such a broad range of skills and experience in many different aspects of changemaking. It also helped me discover and develop my passion for communication which led me to enrol in a Masters of Global Media Communication loved my studies, but being able to apply my knowledge in a practical and meaningful way as the Victorian State Coordinator was invaluable. AYCC gave me the chance to show my commitment to stopping climate change and my experience as a volunteer has allowed me to work much more effectively across Environment Victoria.

\section{ALEX SÖDERLAND}

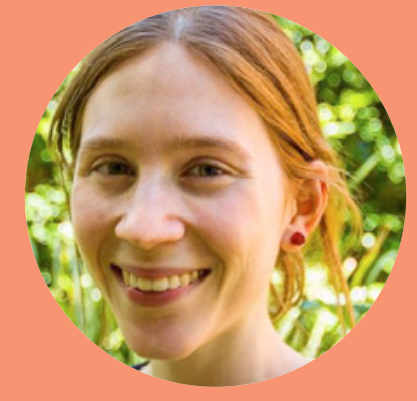

Ijoined AYCC while I was at uni in 2011. I heard about Power Shift from a friend and decided to go, and from then on I was hooked. I volunteered the rest of the time I was at uni, first as a grassroots group convener and then as the Online Coordinator for NSW.

Five years and one Honours degree later, and I'm now at Solar Citizens, which is a community-based organisation bringing together millions of solar owners and supporters to grow and protect solar in Australia.

I'm the Campaigns Coordinator, which means I work on everything from volunteer management, tactics and logistics to digital/online work. Basically. everything I learnt at AYCC. AYCC gave me practical skills and experience that I wouldn't have got anywhere else, skills and experience that are a big part of why I have the job I do today. I learnt about organising and working with communities, and what it means to campaign for change. I also made some amazing friends, many of whom have gone on to work with other organisations in the environment movement.

\section{FLASHBACK}
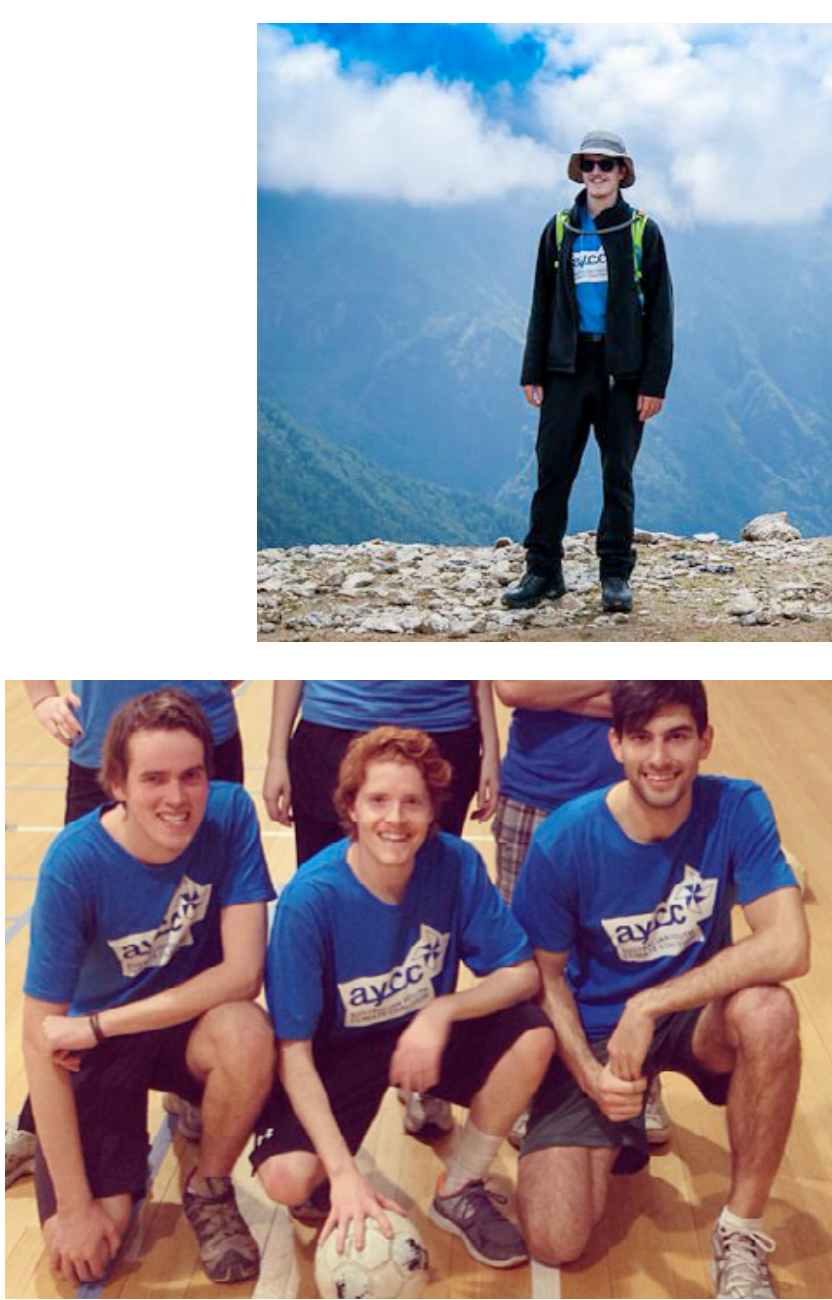

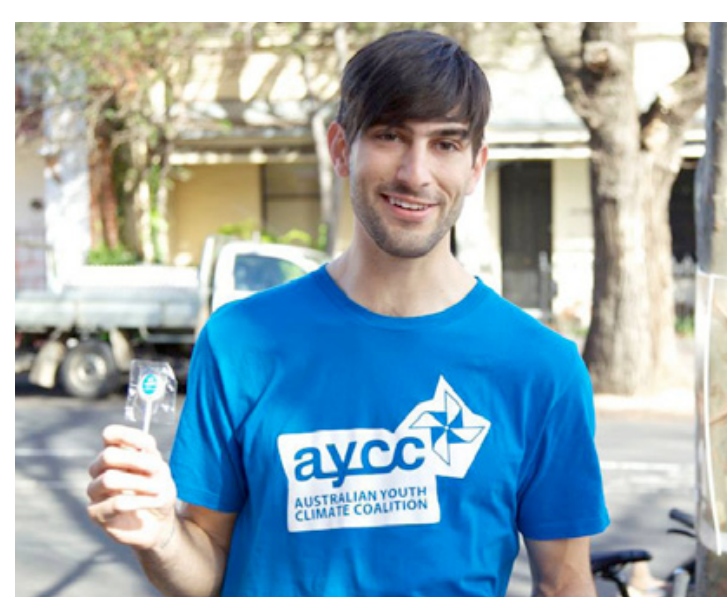

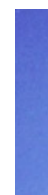

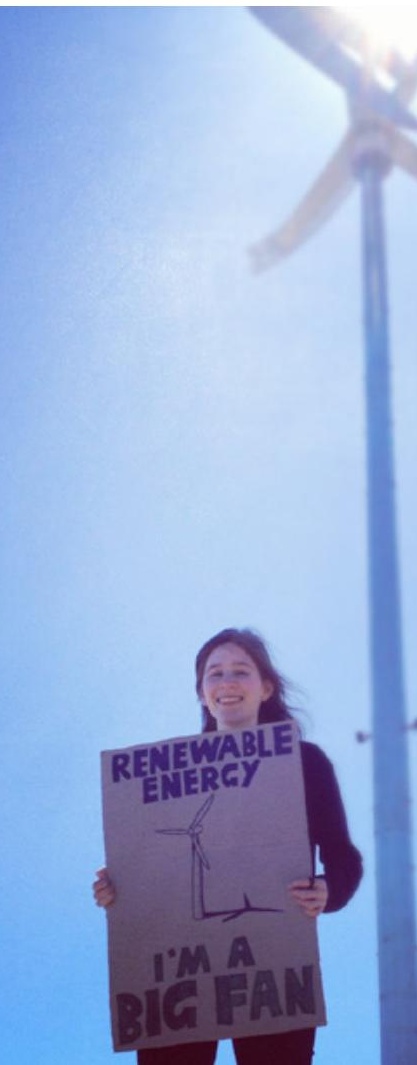

23 
15,024

people pledged to dump their bank, wrote to a bank or signed a petition to protect the Reef and our climate from coal ports.

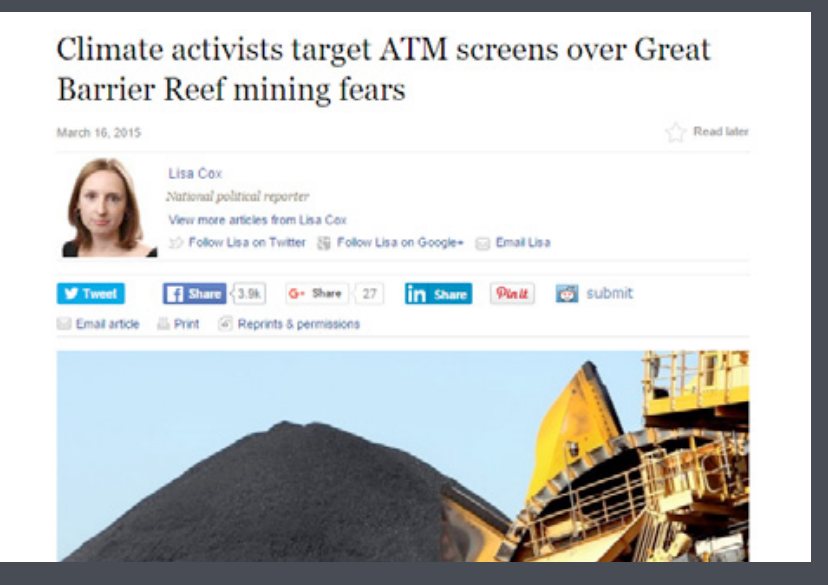

Sydney Morning Herald after ou
"Paint the Town" action

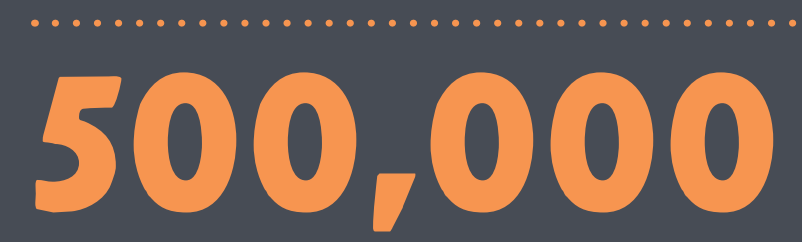

reached per month on Facebook and Twitter

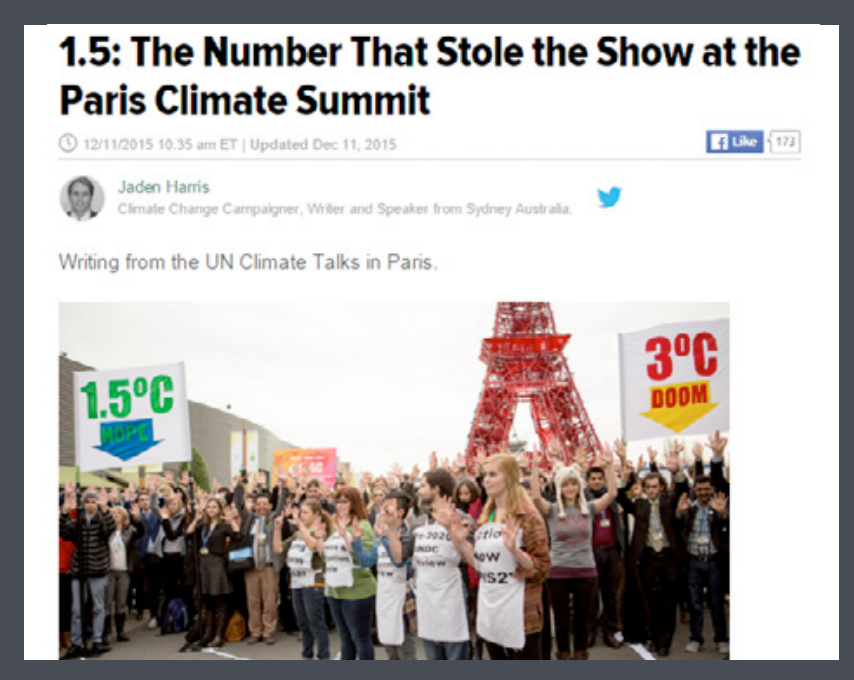

AYCC volunteer Jaden wrot
the Paris Climate Summit

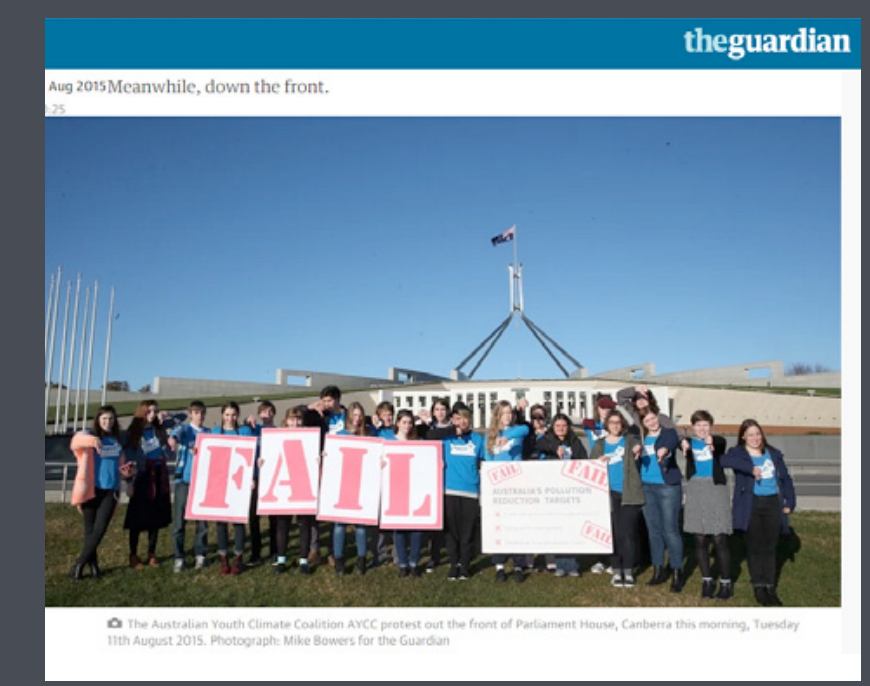

The Guardian covered our "Fail" actions when the carbon price was scrapped

\section{0,000}

online members

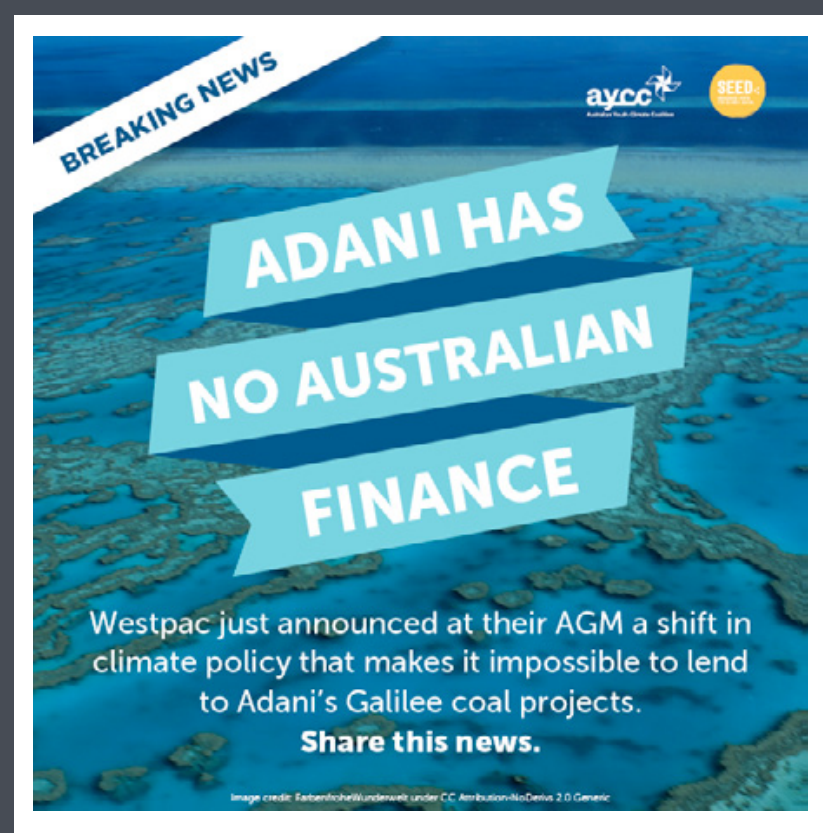

Our celebration graphic after Westpac's AGM, our

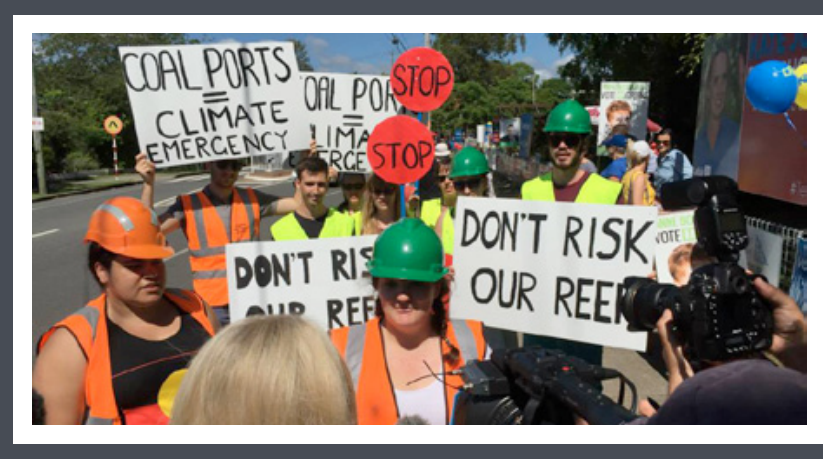

Volunteers
by media

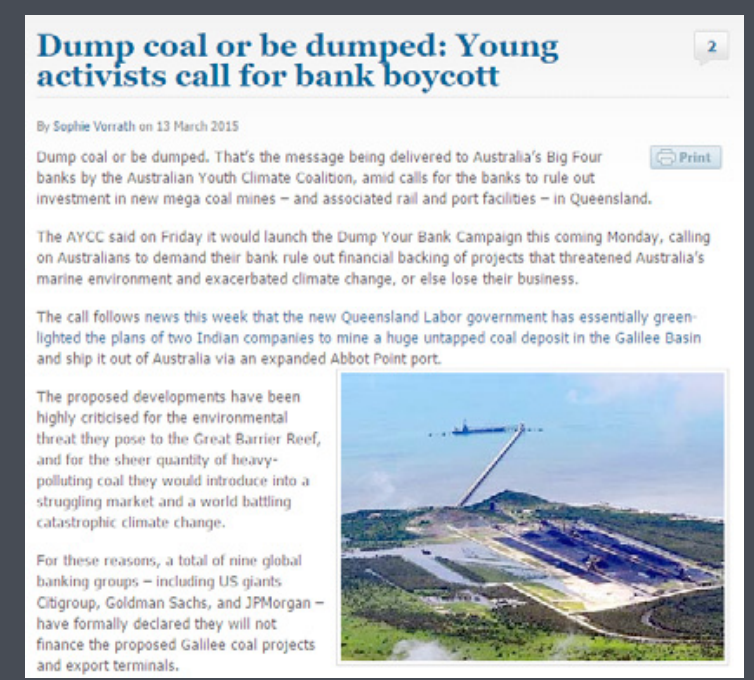

Our "Dump my Bank" campaign in

\section{0}

high school students voted for the future they want to grow up in on our interactive Youth Decide website.
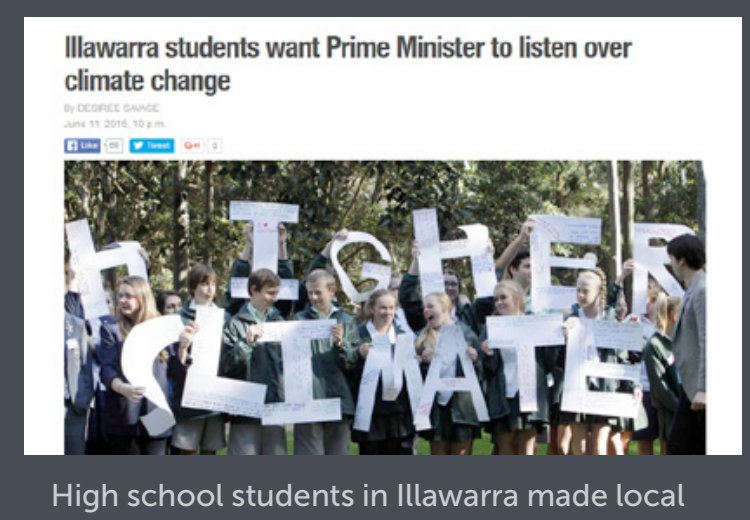
media head

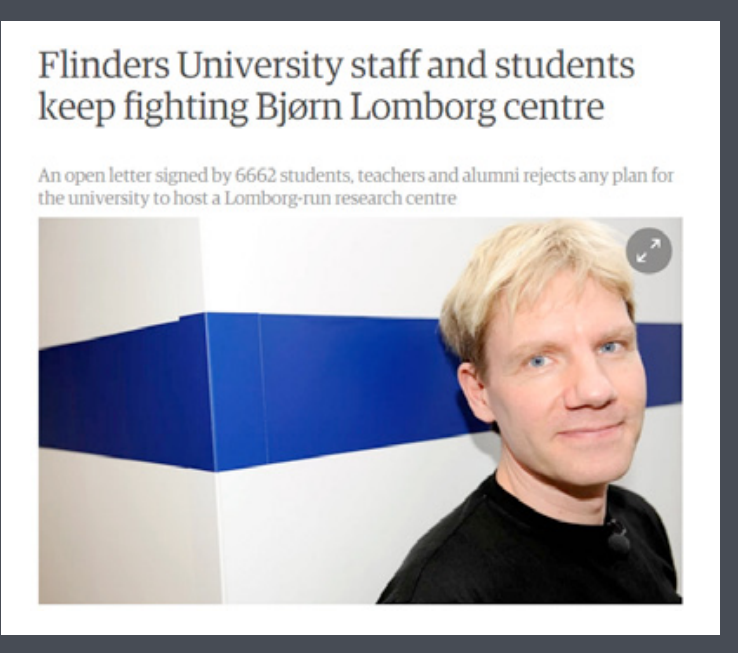

Our campaign to stop anti-climate action
advocate Bjorn Lomborg from setting up at Australian unis had weeks worth of

\section{MEDIA AND \\ ONLINE}

2015 was a big year for the AYCC and Seed in the media. Our campaigns made the front page at a national and state level, volunteers got in front of television cameras with their cheeky actions and loads of volunteers got their own local media in the community

We recorded over 200 media hits throughout the year, with our peak times being the time we covered 1000 ATM screens with our own message the Queensland election, when the government announced its dangerous emissions targets and the Paris climate summit.

Our campaigners were key spokepeople in the Great Barrier Reef campaign, and through our alliances with our friends in the movement we shifted the public narrative on Adani's coal projects in the Galilee Basin

In South Australia, the Repower Port Augusta campaign made several front pages and Dan Spencer (one of our lead campaigners) was interviewed regularly for radio, newspaper and online comment

Pictured are some of our favourite moments from 2015

\section{$4,4,4$}

people signed a petition calling on world leaders to put a ban on all new coal mines at the Paris climate summit.

\section{3,000}

views of our Valentine's Day flashmob at CommBank HQ 


\section{OUR SUPPORTERS}

2015 has been the AYCC's biggest year yet, and it would not have been possible without the support and encouragement of our donors. It has been such a pleasure working with the following individuals and organisations who have invested their time and support into the AYCC, and we thank you for standing by us and encouraging us to achieve our vision.

PURVES

ENVIRONMENTAL FUND

THE BODY SHOP。

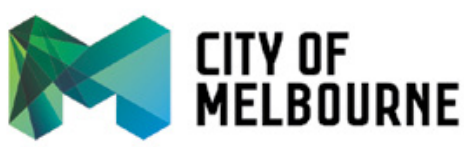

Fúture

Super

MELBOURNE
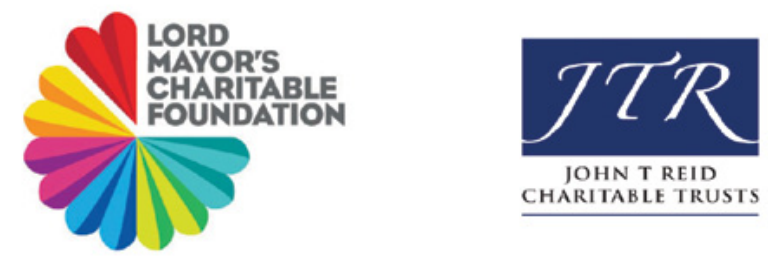

Australian
Communities
Foundation

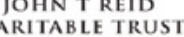

$\therefore$ Climate

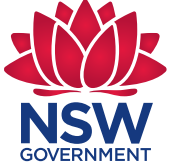

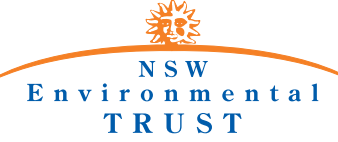

(8)

\section{THANK YOU}

Thank you to the Purves Environmental Fund, a major supporter of the AYCC since 2008. Your support has given the AYCC the ability to grow from strength to strength by providing core funding. support and advice throughout many years. We cannot thank you enoug

To our principal funders, thank you for your support of and confidence in the AYCC. Thank you to: the Mullum Trust, Pace Foundation, Future Super, Diana and Brian Snape AM, Margaret Henderson, Danny Matthews, Madden Sainsbury Foundation and the Duggan Foundation.

To the kind and very generous individuals and organisations who helped us make our Climate Anne Foote Foundation: Lord Mayors Charitable Foundation: the Johnstone Gumption Fund the Rana and Alan Fund and the Fairer Futures Fund as sub funds of the Australian Communities Foundation: the John T Reid Charitable Trust: and the Garry White Foundation.

For your support of the Start the Switch high schools program, thank you to: the NR Peace and Justice Fund; NSW Environmental Trust; NSW Office of Environment and Heritage; the Rober Hicks Foundation, managed by Equity Trustees; the Andrews Foundation; Greater Dandenong City Council; Warringah Council; Maribyrnong City Council; Launceston City Council; Hobart City Council; Boroondara City Council; Adelaide City Council; Clity of Fremantle, Cly of Melville, Hume City Council, Hobsons Bay Councli, Moonee Valley City Council; City of Yarra; Parramatta City Counc University of Wollongong; and The Lord Mayor's Charitable Foundation; Go Energy; and Taronga Zoo.

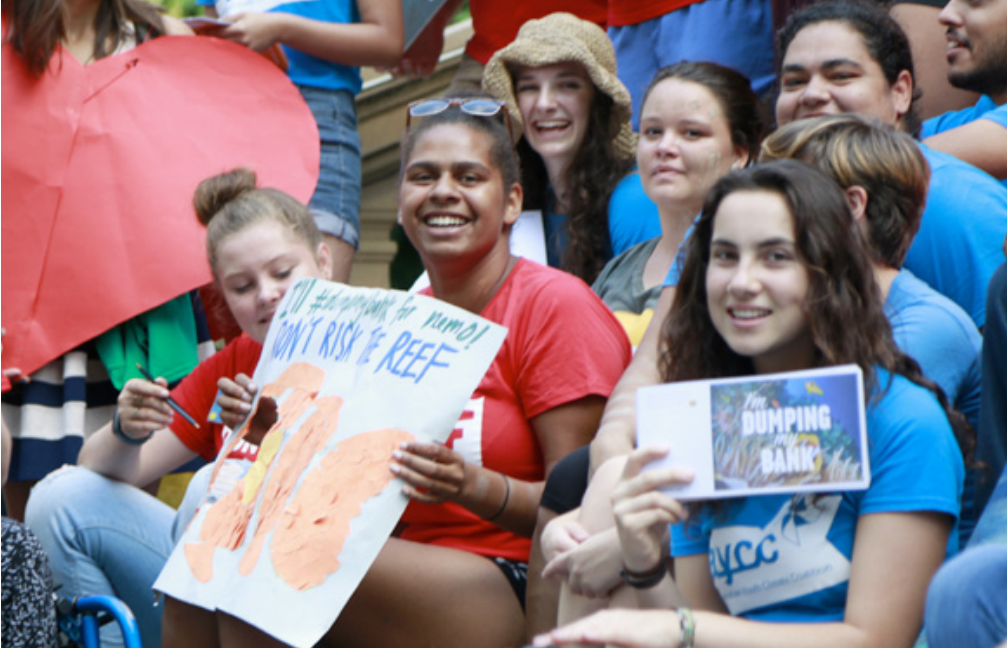

To the supporters of the Seed Indigenous Youth Climate network a huge thank you to: The McKinnon Family Foundation, the United States Consulate of Melbourne, Oxfam Australia, 350.org Stephen Whately, Anne Coombs and Susan Varga, Future Leaders, Wagga Wagga Presentation Sisters, the Sir James McNeill Trust, Perpetual Foundation - B. U. Andrews Family Endowment, and the Pratt Family Foundation.

To all of those who have supported us to make AYCC campaigns even bigger and more impactful throug your generous donations and expertise, thank you to: Max Fabre Foundation and Ross Knowles.

Thank you to the organisations across many sectors for your help, expertise, and encouragement 350.org, Australian Marine Conservation Society, Australian Manufacturing Workers' Union, the Mackay Conservation Group, Oxfam Australia, Plan International Australia, Earth Hour and WWF Australia.

To all of the donors who supported our efforts to protect the Great Barrier Reef through "For the Love of," thank you so much.

Lastly, but certainly not least, to our monthly donors, our Champions of Change - parents, friends, family members and supporters, thank you so much for your generous support.

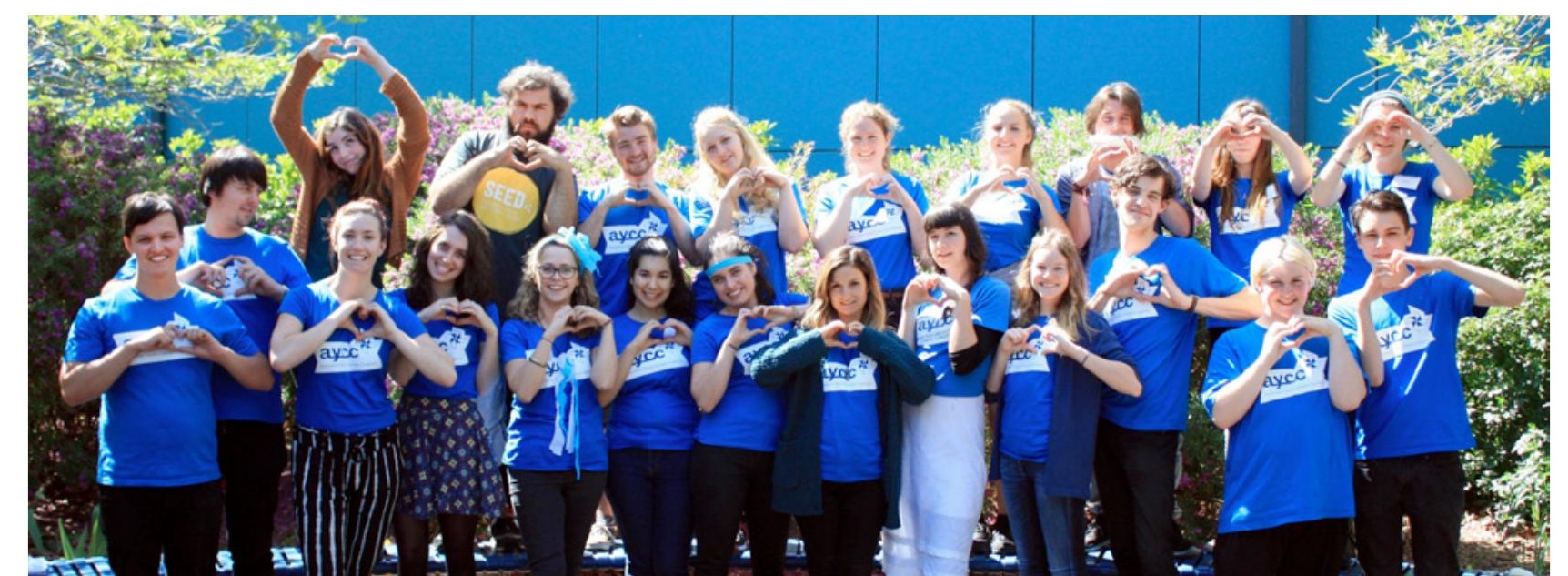

\section{OUR WONDERFUL STAFF AND VOLUNTEERS}

Thank you to our tireless state coordinators: Lovisa Muyderman, Maddie Sarre, Liv Metter, Katherine Whitmore, Olivia Hill, Jackson Turner, Grace Liley, Renaire Druery Emma Bliss, Dean Leggo, Tallara Gray, Murrawah Johnson, Wilfred Reuben, Paul Gorrie, Corina Ritchie, Zac Romagnoli-Townsend, Vanessa Farrelly, Clayton Simpson, Jordan Wimbus and Nathan Kropinyer

Our wonderful staff: Kirsty Albion, Amelia Telford, Jem Bamford, Gemma Marshall, Kelly Mackenzie, Julie Hirsch, Jackie Colmar, Larissa Baldwin.
Tom Reddington, Alicia Robitaille, Tracey Martinovich, Luke Sweet, Daniel Spencer, Ella Weisbrot, Amelia Anthony, Laura Melville, Jess McGeachin, Alex Murray, James Collopy, and Phoebe Howe.

Our supportive mentors and facilitators Karrina Nolan and Holly Hammond.

And our fantastic board in 2015: Renee Carr, Claire Snyder, Lucy Manne, Tom Dreyfus, Nayuka Gorrie, Ebony Bennett, David Pitts and Bronwyn Lee. 


\section{We're building a generation-wide movement to solve the climate crisis}

OUR MISSION

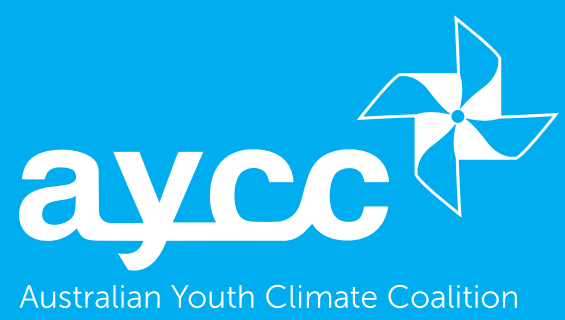

Copyright $\odot 2016$ Australian Youth Climate Coalition All rights reserved. This report any portion thereof may not be reproduced or used in any manner whatsoever without the express written permission of the AYCC.

Images Copyright - Jeff Tan, Daniel A'Vard, Patrick McCarthy, James Thomas, Karl Goodsell and many other talented AYCC volunteers.

Printed on 100\% Post-Consumer waste. 